\title{
Mansonellosis: current perspectives
}

This article was published in the following Dove Press journal:

Research and Reports in Tropical Medicine

\section{Thuy-Huong Ta-Tang' James L Crainey ${ }^{2}$ \\ Rory J Post ${ }^{3,4}$ \\ Sergio LB Luz ${ }^{2}$ \\ José M Rubio'}

'Malaria and Emerging Parasitic Diseases Laboratory, National Microbiology Center, Instituto de Salud Carlos III, Majadahonda, Spain; ${ }^{2}$ Laboratory of Infectious Disease Ecology in the Amazon, Oswaldo Cruz Foundation, Instituto Leônidas e Maria Deane, Manaus, Brazil; ${ }^{3}$ School of Natural Sciences and Psychology, John Moores University, Liverpool, ${ }^{4}$ Department of Disease Control, Faculty of Infectious Tropical Diseases, London School of Hygiene and Tropical Medicine, London, UK
Correspondence: José M Rubio Carretera Majadahonda-Pozuelo km 2.5, Majadahonda, Madrid 28220, Spain

Tel +34918223420

Fax+34915097034

Email jmrubio@isciii.es
Abstract: Mansonellosis is a filarial disease caused by three species of filarial (nematode) parasites (Mansonella perstans, Mansonella streptocerca, and Mansonella ozzardi) that use humans as their main definitive hosts. These parasites are transmitted from person to person by bloodsucking females from two families of flies (Diptera). Biting midges (Ceratopogonidae) transmit all three species of Mansonella, but blackflies (Simuliidae) are also known to play a role in the transmission of M. ozzardi in parts of Latin America. M. perstans and M. streptocerca are endemic in western, eastern, and central Africa, and M. perstans is also present in the neotropical region from equatorial Brazil to the Caribbean coast. $M$. ozzardi has a patchy distribution in Latin America and the Caribbean. Mansonellosis infections are thought to have little pathogenicity and to be almost always asymptomatic, but occasionally causing itching, joint pains, enlarged lymph glands, and vague abdominal symptoms. In Brazil, M. ozzardi infections are also associated with corneal lesions. Diagnosis is usually performed by detecting microfilariae in peripheral blood or skin without any periodicity. There is no standard treatment at present for mansonellosis. The combination therapy of diethylcarbamazine plus mebendazole for $M$. perstans microfilaremia is presently one of the most widely used, but the use of ivermectin has also been proven to be very effective against microfilariae. Recently, doxycycline has shown excellent efficacy and safety when used as an antimicrobial against endosymbiotic Wolbachia bacteria harbored by some strains of M. perstans and M. ozzardi. Diethylcarbamazine and ivermectin have been used effectively to treat $M$. streptocerca infection. There are at present no estimates of the disease burden caused by mansonellosis, and thus its importance to many global health professionals and policy makers is presently limited to how it can interfere with diagnostic tools used in modern filarial disease control and elimination programs aimed at other species of filariae.

Keywords: mansonellosis, filariasis, . perstans, . ozzardi, $M$. streptocerca, neglected disease

\section{Introduction}

Mansonellosis is a filarial disease caused by various species of the genus Mansonella (Nematoda; Filarioidea; Onchocercidae) that use humans as their primary definitive hosts. ${ }^{1}$ By most modern definitions, there are just three filarial species considered responsible for causing human mansonellosis: Mansonella perstans, Mansonella streptocerca, and Mansonella ozzardi. ${ }^{1-5}$ Other Mansonella spp., like the chimpanzee parasite Mansonella rodhaini, occasionally infect humans, and some can use humans as definitive hosts, ${ }^{6-9}$ producing patent infections with circulating microfilariae. However, they are rare infections in humans in comparison with other primates, and by convention they are not considered to cause mansonellosis. ${ }^{1-5}$

As $M$. ozzardi was originally the only parasite of the Mansonella genus known to infect humans, ${ }^{10}$ the term "mansonellosis" and its synonym "mansonelliasis" were, until the mid-1980s, applied only to infections caused by this one species. ${ }^{11-15}$ The 
modern use of the term ${ }^{1-5}$ began only after Orihel and Eberhard revised the genus Mansonella and added M. perstans and M. streptocerca. ${ }^{16,17}$ Prior to this, a number of systems of nomenclature were used to describe Mansonella parasite infections, ${ }^{18-24} \mathrm{eg}$, mansonellosis was usually restricted to infections caused by $M$. ozzardi $i^{19,20}$ and the terms "perstans filariasis" and "streptocerciasis" were often used to describe infections with M. perstans and M. streptocerca, respectively. ${ }^{18,21-24}$

Among the known human filarial infections, mansonellosis is probably the most prevalent ${ }^{23,25}$ but nevertheless the least studied, and can be considered the most neglected filariasis. Certainly, it is more prevalent and more neglected than other filarial diseases like lymphatic filariasis, onchocerciasis, and loiasis. It can even probably be considered one of the most neglected of all the tropical diseases, as it is subject to more neglect than schistosomiasis, taeniasis, echinococcosis, or rabies. ${ }^{1-5}$

The three species of Mansonella parasite which cause mansonellosis in humans vary in biological, clinical, and epidemiological characteristics (Table 1). ${ }^{1-5,18,23-25}$ The life cycles for all three species are similar, involving development in two hosts: an insect and a primate. ${ }^{4,15,25-27}$ Humans are the only known natural vertebrate host for M. ozzardi, but other primates can serve as natural hosts for M. perstans and M. streptocerca. ${ }^{2,28}$ All of the known insect vectors of mansonellosis are from the Diptera taxonomic grouping. The known vectors of M. perstans and M. streptocerca are from the biting-midge genus Culicoides. M. ozzardi, however, is not exclusively transmitted by Culicoides..$^{15,26,27,29} \mathrm{~A}$ range of non-Culicoides Ceratopogonidae biting midges and blackflies from the genus Simulium are known to be capable of transmitting M. ozzardi (Table 1). 15,26,27,29

Females of all known vectors of mansonellosis consume blood meals in order for their eggs to mature. ${ }^{26,27}$ Microfilariae are ingested by the vector when a female vector takes a blood meal from an infected host. The microfilariae penetrate the insect's gut and go through several maturation stages in the thoracic flight muscles over 6-12 days before migrating to the head and proboscis, from where they can be transferred to a primate when the vector takes its next blood meal., ${ }^{46,27}$ During the blood meal, the third-stage (infective) filarial larvae actively break out of the mouthparts and penetrate into skin via the bite wound before migrating and maturing into adult worms. Males and females mate, and female worms begin to produce unsheathed microfilariae that circulate in the blood (M. perstans and M. ozzardi) or diffuse into the skin (M. streptocerca and M. ozzardi) of the primate host. ${ }^{4,26,27}$ Practical diagnostic guides often describe all three species as having aperiodic microfilariae that circulate in peripheral blood or skin throughout the day and night, ${ }^{30}$ although reports of cryptic periodicity for both M. perstans and M. ozzardi exist. ${ }^{4,31,32}$

Most of what is known of mansonellosis and the geographic distribution of Mansonella parasites is based on the morphological identification of microfilariae recovered from blood or skin-snip samples. ${ }^{23}$ With adult filarial parasites, almost impossible to recover, even accounts of "new species" of Mansonella or Mansonella-like parasites have often been based solely on the morphological characteristics of microfilariae..$^{33-36}$ The species-diagnostic characters of microfilariae are sometimes difficult to see, and can vary greatly with sample preservation, mounting, and staining procedures ${ }^{4-38}$ and hence microfilariae are easily misidentified. ${ }^{39,40}$ This has resulted in a number of questionable "new" Mansonella species being described, ${ }^{33-36}$ some controversial filarial parasite-distribution maps (generated by Mansonella parasites being confused with other filarial parasites and vice versa), ${ }^{39,40}$ inappropriate clinical treatments, ${ }^{39}$ and even dubious clinical symptoms being attributed to mansonellosis infections ${ }^{41}$ For example, there has only ever been one very tentative report of $M$. perstans encountered in the cerebrospinal fluid of patients. The report concerned patients from the Zambezi valley region of Zimbabwe, ${ }^{41}$ and has subsequently been attributed to a zoonotic filariasis, ${ }^{7,42,43}$ but there are a number of published papers where M. perstans is described as occasionally causing severe neurological symptoms. ${ }^{15,44-47}$

Following the development of filarial parasite-diagnostic polymerase chain reaction (PCR) assays, many ambiguities concerning species' distribution and "new species" have been resolved, and most modern filarial parasite research, including mansonellosis research, now suffers from far fewer parasite-identification uncertainties than used to be the case. ${ }^{48-53}$ Almost all of these assays use mitochondrial or rDNA target sequences, and were developed from molecular systematic studies (see "Diagnosis" section), which used DNA sequences from these regions to constructed molecular filarial parasite phylogenies. ${ }^{48-57}$ Although these mitochondrial and rDNA phylogenetic studies and more recent multilocus sequence typing challenged traditional morphology-based phylogenies of the species within the family Onchocercidae, ${ }^{58}$ none has hitherto challenged the morphology-based genus Mansonella proposed by Eberhard and Orihel in 1984, from which the modern use of the term "mansonellosis" has arisen. ${ }^{16,17,50,54-60}$

Later molecular phylogenies investigated the origins of the filarial endosymbiont Wolbachia, which infects many 
Table I Main characteristics of Mansonella perstans, Mansonella ozzardi, and Mansonella streptocerca

\begin{tabular}{|c|c|c|c|}
\hline & M. perstans & M. streptocerca & M. ozzardi \\
\hline \multirow[t]{2}{*}{ Microfilaria tail } & Blunt, rounded tail, body & Hooked shape & Long, thin, pointed tail \\
\hline & Nuclei extend to tip of tail & Body nuclei extend to tip of tail & Body nuclei do not extend to tip of tail \\
\hline Sheath in microfilariae & Unsheathed & Unsheathed & Unsheathed \\
\hline Microfilariae: & Aperiodic microfilariae & Aperiodic microfilariae & Non-periodic microfilariae \\
\hline periodicity and & Blood & $\begin{array}{l}\text { Skin of the upper trunk and } \\
\text { shoulder girdle }\end{array}$ & Blood and skin \\
\hline $\begin{array}{l}\text { Microfilaria: length } \times \\
\text { diameter }\end{array}$ & $200 \times 4-5 \mathrm{~mm}$ & $180-240 \times 3-5 \mathrm{~mm}$ & $163-203 \times 3-5 \mathrm{~mm}$ \\
\hline Adults measurements & $3.5-4.5 \mathrm{~cm}$, ㅇ $5-8 \mathrm{~cm}$ & के $1.3-1.8 \mathrm{~cm},+2.7 \mathrm{~cm}$ & के $2.4-2.8 \mathrm{~cm}$, ㅇ $3.2-8.1 \mathrm{~cm}$ \\
\hline Adults localization & $\begin{array}{l}\text { Serous body cavities, mainly } \\
\text { peritoneal, but may also appear } \\
\text { subcutaneously }\end{array}$ & $\begin{array}{l}\text { Subcutaneous tissues of the } \\
\text { dermis }\end{array}$ & $\begin{array}{l}\text { Thoracic cavity and mesenteries of the } \\
\text { peritoneal cavity }\end{array}$ \\
\hline \multirow{4}{*}{$\begin{array}{l}\text { Central America } \\
\text { South America }\end{array}$} & Culicoides spp. (biting midges) & Culicoides spp.(biting midges) & \\
\hline & & & - Simulium sanguineum (Panama) \\
\hline & Culicoides spp. (biting midges) & & $\begin{array}{l}\text { Simuliidae } \\
\text { - Simulium exiguum (Argentina); } \\
\text { S. amazonicum (Venezuela, Colombia, } \\
\text { and Brazilian Amazon); S. argentiscutum } \\
\text { (Colombia and Brazilian Amazon); } \\
\text { S. oyapockense (Colombia, Venezuela, } \\
\text { and Brazil); S. sanguineum (Colombia); } \\
\text { S. guyanensis and S. sanchezi (Venezuela); } \\
\text { S. minusculum (Guyana) }\end{array}$ \\
\hline & & & $\begin{array}{l}\text { Ceratopogonidae } \\
\text { - Culicoides insinuatus (Colombia); } \\
\text { C. guttatus (Guyana, Suriname and } \\
\text { Venezuela); C. paraensis (French Guiana, } \\
\text { Argentina and Bolivia); C. debilipalpis } \\
\text { (Bolivia and Argentina); C. lahillei } \\
\text { (Argentina) }\end{array}$ \\
\hline Caribbean & & & $\begin{array}{l}\text { C. furens (Haiti and St Vincent); } \\
\text { C. barbosai (Haiti); C. paraensis? } \\
\text { (St Vincent); C. phlebotomus (Trinidad); } \\
\text { Leptoconops bequaerti (Haiti) }\end{array}$ \\
\hline & Central and west Africa, South & Central and west Africa, western & Latin America and Caribbean islands \\
\hline \multirow{2}{*}{$\begin{array}{l}\text { distribution } \\
\text { Reported clinical }\end{array}$} & America & Uganda & \\
\hline & Often asymptomatic & Often asymptomatic & Often asymptomatic \\
\hline symptoms & $\begin{array}{l}\text { Itching, pruritus, joint pains, } \\
\text { enlarged lymph glands, Calabar } \\
\text { swelling, neurological manifestations }\end{array}$ & $\begin{array}{l}\text { Dermatitis, pruritus, rash, } \\
\text { papular skin, inguinal adenopathy, } \\
\text { occasional dizziness }\end{array}$ & $\begin{array}{l}\text { Moderate fever, headache, articular pain, } \\
\text { rash, sensation of coldness in legs, foot } \\
\text { edema and face edema, keratitis, or corneal } \\
\text { opacity }\end{array}$ \\
\hline \multirow[t]{6}{*}{ Treatment } & Diethylcarbamazine + mebendazole: & Diethylcarbamazine: 6 mg/kg/day & Ivermectin: $200 \mu \mathrm{g} / \mathrm{kg}$, single dose \\
\hline & $200 \mathrm{mg} / / 2$ hours $+100-200 \mathrm{mg} / \mathrm{day}$ & $\times 12$ days & Not active against the adult worm \\
\hline & $\times 21$ days & Ivermectin: I $50 \mu \mathrm{g} / \mathrm{kg}$, single & \\
\hline & Mebendazole: $100 \mathrm{mg} / 12$ hours $\times$ & dose; not active against the adult & \\
\hline & 30 days & worm & \\
\hline & Doxycycline: $200 \mathrm{mg} /$ day $\times 6$ weeks & & \\
\hline
\end{tabular}

(though not all) filarial parasites. ${ }^{61-64}$ Data from these studies suggested that filarial parasites had acquired Wolbachia endosymbionts several times independently during the evolution of Onchocercidae. ${ }^{62-64}$ These Wolbachia endosymbionts have important roles in the pathology of onchocerciasis and lymphatic filariasis, and are also necessary for the reproduction and development of filarial parasites that cause these diseases. This has made them an important target for therapeutics. ${ }^{65}$ 
The Wolbachia bacteria that infect M. ozzardi and M. perstans appear to share a common origin, but are genetically very distinct (belonging to the F superclade of Wolbachia) from the Wolbachia known to cause disease pathologies. ${ }^{64}$ It is presently not clear if what is known about other filarial Wolbachia can be safely extrapolated to the Mansonella Wolbachia endosymbionts and if they have a hitherto-uncharacterized role in mansonellosis pathology or indeed what their role in Mansonella-parasite development and reproduction is. ${ }^{65,66}$ However, in one clinical trial in Mali, antibiotic treatment with doxycycline was seen to provide sustained clearance of $M$. perstans parasitemias 12 months following treatment, suggesting that Wolbachia may have an important role in the reproduction and survival of adult worms. ${ }^{67}$

Wolbachia from $M$. perstans cannot be easily detected, and some $M$. perstans parasites may not be infected. ${ }^{66-69}$ It has been proposed that Mansonella parasites may have acquired their F-clade Wolbachia (the only Wolbachia superclade found in both arthropod and filarial worm hosts) more recently than other filariae, and it may not be an essential symbiont for some Mansonella spp. and strains. ${ }^{66}$ Consistent with this is the notion that $M$. perstans may be a species complex, and a potential new species or subspecies of $M$. perstans was recently described from rDNA ITS1 sequences. This potential "new species" was recovered from human blood samples taken in Gabon, and has provisionally been called Mansonella sp. "Deux". ${ }^{60}$ A phylogenetic tree, constructed with Treecon software ${ }^{70}$ by the neighbor-joining method, shows that Mansonella sp. Deux forms a sister clade to standard forms of $M$. perstans from Brazil and Africa (Figure 1). However, further studies should be performed to characterize this new species and evaluate its clinical significance in humans. ${ }^{60}$

\section{Epidemiology and distribution}

Mansonella parasites are among the most common cause of blood parasitemias and are encountered widely across Africa and Latin America. ${ }^{3,4,18,23,25,71}$ M. perstans is considered the most common of the mansonellosis parasites and is endemic in a large portion of sub-Saharan Africa, as well as a northern part of the Amazon rainforest stretching from equatorial Brazil to the Caribbean coast of South America, with molecular analysis suggesting that the parasite arrived in South America relatively recently and most likely as a consequence of the slave trade (Figure 2). ${ }^{18,23,25,50}$ From the mid-1920s until the early 1970s, M. perstans was frequently recorded as occurring in Papua New Guinea, but there is very little primary-source data to support this and no recent survey

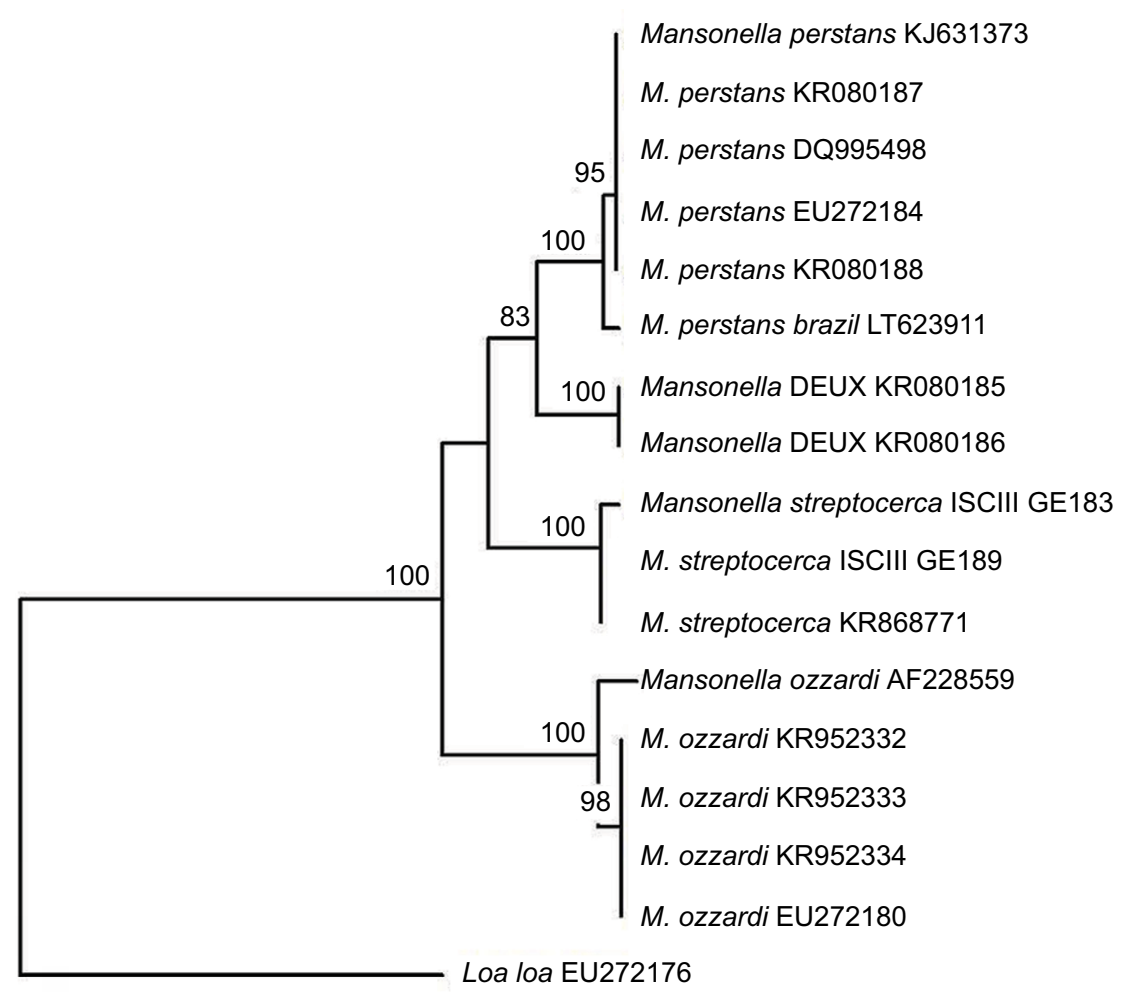

Figure I Neighbor-joining phylogenetic tree.

Notes: Tree compares the ITSI partial sequences of human Mansonella spp. present in the GenBank (accession numbers are indicated in parentheses or with an internal code when not submitted to the GenBank). A sequence of $L$. loa (EU272176) was used as the out-group. Significant bootstrap values are indicated. 

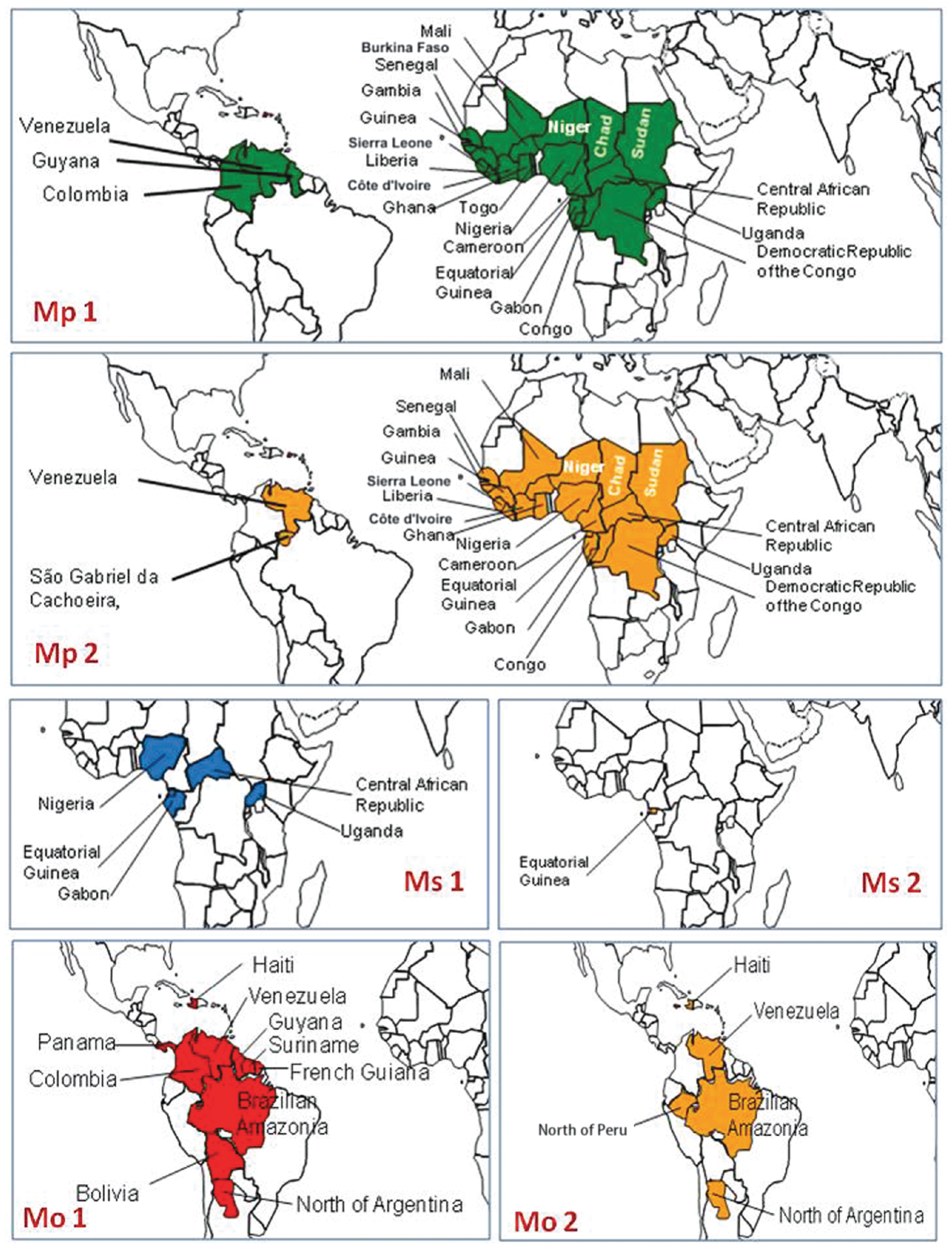

Figure 2 Distribution of human Mansonella based on published reports before and after the year 2000.

Notes: I, Before; 2, after.

Abbreviations: Mp, Mansonella perstans; Ms, Mansonella streptocerca; Mo, Mansonella ozzardi. 
data that indicate its occurrence anywhere in the Eastern hemisphere outside continental Africa. ${ }^{71}$ Overall, more than 100 million people may be infected by $M$. perstans, and it is estimated that 600 million people live at high risk of contracting an infection in Africa alone. ${ }^{23}$

A strong epidemiological link between banana plantations and $M$. perstans prevalence and parasitic loads was recorded more than 100 years ago, before its Culicoides vectors had been incriminated in its transmission (Table 1). ${ }^{4,32,72,73}$ Sharp (the man who incriminated Culicoides in the transmission of $M$. perstans) was aware of this epidemiological link and presumably also that $C$. austeni uses banana-tree stumps and litter to support its larval development (because this had been published in the original description of the C. austeni). It is not clear to what extent, if any, the banana-plantation epidemiological observation led to elucidation of the life cycle of $M$. perstans. ${ }^{32}$ Certainly, the epidemiological M. perstans studies that have been carried out since then have not provided much more significant understanding of the parasites' biology and transmission dynamics. However, they have shown that in endemic areas, prevalence of $M$. perstans infection is higher among older age-groups and that men are at more risk of infection than women. ${ }^{23-25}$ Recently, geographic informationsystem data obtained from remote satellite imaging have been used in conjunction with $M$. perstans prevalence from school surveys to show $M$. perstans distribution varies with diurnal temperature range, vegetation, and cattle density. ${ }^{74}$ Epidemiological studies that have tried to link $M$. perstans parasitemias with clinical symptoms have thus far failed to detect any significant correlations. ${ }^{23,24}$

M. streptocerca seems to have a distribution limited to continental Africa, where it occurs in the tropical rainforest areas of central and west Africa, as well as in Uganda (Figure 2). 4,18,25 Perhaps because the skin-snip biopsies required for its epidemiological monitoring are more invasive and painful than the blood sampling required for $M$. perstans surveys, or perhaps because blood sampling is simply more commonly done for other epidemiological studies, there have been fewer epidemiological surveys investigating $M$. streptocerca epidemiology. ${ }^{4,25}$ As with $M$. perstans and $M$. ozzardi and many other filarial infections, prevalence rates of $M$. streptocerca are highest in the oldest age-groups studied and higher among men than women in endemic areas. ${ }^{21,25,75}$ M. streptocerca is transmitted by various species of Culicoides and some of the same vector species that transmit M. perstans, although there are too few data available to evaluate properly whether its distribution is influenced by the same ecological drivers as $M$. perstans (Table 1). ${ }^{15,77,78}$ The few epidemiological studies that have tried to link patent $M$. streptocerca infections with clinical symptoms have encountered similar rates of skin disease among those infected and those uninfected in their study areas. ${ }^{75,76}$

M. ozzardi has a patchy geographic distribution across Latin America. It has been recorded from southern Mexico to northwestern Argentina, but has not been reported in Chile, Uruguay, or Paraguay., 3,4,18,25,29 The parasite occurs on several Caribbean Islands, and like M. perstans has even been recorded in Papua New Guinea, although recent reports of its occurrence in the region are notable by their absence (Figure 2)., ${ }^{4,71}$ In the Caribbean region, the parasite is transmitted by a diverse range of biting midges from the family Ceratopogonidae, whereas in Central and South America it is known only to be transmitted by biting midges from the genus Culicoides and blackflies from the genus Simulium. 3,4,15,29,79-90 Because of these vectorial differences, it was once thought that $M$. ozzardi from the Caribbean islands and those from continental South America might be different species (Table 1). ${ }^{85,91}$ Artificial-infection experiments and the recent publication of DNA sequences, however, strongly indicate that parasites from the two regions are morphologically, biologically, and genetically near identical, and thus that they are most parsimoniously regarded as just one species. ${ }^{2,17,28,48,50,58}$

Even though the various populations of $M$. ozzardi are best considered as belonging to the same species, it is not safe to assume, for example, that the epidemiology of M. ozzardi in the Brazilian Amazon region is more or less identical to its epidemiology in the Caribbean, because of the great diversity of vectors involved. ${ }^{3,4,15,29,79-90}$ In the Amazon region, although it is transmitted by a range of Simulium and Culicoides species, the parasite appears to be most commonly transmitted by Simulium vectors from the amazonicum species group and to have a distribution that follows the riverine breeding sites of these Simulium vectors. ${ }^{29,79}$ In Trinidad, by way of contrast, the only known vector is Culicoides phlebotomus (which uses sandy-beach breeding sites), and the parasite thus has a coastal distribution. . $^{15,88}$

However, it is important to note that vector distribution is not the only important driver of $M$. ozzardi distribution. For example, repeated M. ozzardi surveys in the Brazilian Amazonian state of Rondônia have found the area completely devoid of the parasite, despite the fact that the region shares a similar ecology and blackfly fauna to the neighboring Amazonas state. It has been proposed that low levels of human immigration may play an important role in the parasite's failure to establish in the region. ${ }^{91}$ However, data from tourists indicate that $M$. ozzardi infections are easily acquired, and as Rondônia is 
surrounded by highly endemic areas, migration levels would have to be very low indeed for this to be the most important factor limiting the parasite's establishment in the region. ${ }^{19,91-95}$ Furthermore, since the first discovery of $M$. ozzardi, surveys have shown that very small isolated foci (in some cases, the size of a single village) on numerous islands can sustain themselves over prolonged periods, suggesting that even low levels of migration could supply a sufficient parasite reservoir to allow for the establishment of a new focus if the other epidemiological criteria for establishment were met. ${ }^{96}$ In Cameroon, it has been proposed that some areas of low onchocerciasis endemicity are explained by "zooprophylaxis", whereby exposure to simuliid bites from insects infected with cattle parasite Onchocerca ochengi provide something akin to natural vaccination. ${ }^{97,98}$ In light of these observations, the recent discovery of highly prevalent zoonotic Mansonella parasites in anthropophilic simuliid vectors of the region may thus been seen as an alternative explanation as to why M. ozzardi has failed to establish in Rondônia. ${ }^{94,98,99}$

In line with epidemiological studies of other mansonellosis, research in the Brazilian Amazon has identified outdoor workers, males, and older community members as being at elevated risk of developing $M$. ozzardi parasitemias. ${ }^{101,102}$ Importantly too, $M$. ozzardi parasitemias from this region have been shown to be positively correlated with joint pain, leg chills, headaches, and corneal lesions. ${ }^{103,104}$

\section{Pathology and symptomatology of mansonellosis}

Although mansonellosis has very broad global distribution and is almost certainly the most common form of filarial parasite infection, little is known about its pathology or symptomatology, with most health experts and policy makers viewing the parasites as largely innocuous and only rarely causing mild clinical symptoms. ${ }^{4,5,18,25}$ However, as mentioned, recent studies investigating $M$. ozzardi infections in the Brazilian Amazon have found significant correlations between $M$. ozzardi infections and certain clinical symptoms, and other similar epidemiological studies investigating $M$. ozzardi in other regions and $M$. perstans and $M$. streptocerca have repeatedly failed to correlate clinical symptoms robustly with patent mansonellosis infections. ${ }^{101-107}$

This of course does not mean that mansonellosis is necessarily always completely asymptomatic outside the Brazilian Amazon region. Most of the epidemiological studies used to investigate symptomatology have had very small sample sizes and used diagnostic techniques of low sensitivity (ie, light microscopy-based diagnosis of thick blood smears), and thus could not be expected to have had sufficient statistical power to detect subtle or complex correlations. ${ }^{24,75,76,101-109}$ Recent observations suggest that mansonellosis infections can influence the human immune system's response and this can influence the development of secondary infections, like malaria. ${ }^{110}$ As mansonellosis infections are chronic and occur in many tropical areas where a great number of other infectious diseases also exist, it is possible that the way mansonellosis influences other pathogenic infections could actually account for a very substantial proportion of its pathogenicity and its total disease burden., 4,5,18,23,25 At present, however, although there have been many accounts of mansonellosis parasites co-occurring with other parasites, there have been very few accounts about how mansonellosis influences the pathogenicity of other infectious diseases..$^{96,110-114}$

Most symptoms ascribed to $M$. perstans infections in modern scientific literature are based on symptoms that have been recorded in case study reports. ${ }^{23,25,44,115,116}$ As most of these reports are based on the treatment of tourists and expatriate Europeans and North Americans returning home from endemic areas, and not on people who have lived all their lives in endemic areas, it is not clear whether the symptoms reported from these studies can be used to compile a clinical picture that represents all or even most infections caused by mansonellosis..$^{23,25,44,116,117}$ Based on these reports, M. perstans can be considered to have little pathogenicity and almost always to be asymptomatic, but it can occasionally cause itching, joint pains, enlarged lymph glands, and vague abdominal symptoms. . $23,25,116,117$

High-level eosinophilia are regularly observed in some but not all patients with $M$. perstans infections, probably as a consequence of the body's reaction against the adult worm, rather than against microfilariae. ${ }^{118} \mathrm{M}$. perstans is also reported to be able to induce dermatological symptoms like the Calabar swellings of loiasis, fever, headaches, and pain in bursae and/or joint synovia or in serous cavities. ${ }^{23,25,44,118}$ There has also been ocular pathology ascribed to M. perstans in which yellowish nodules develop in the bulbar conjunctiva; it has been reported that this pathology can on occasion provoke edema of the eyelids and proptosis. ${ }^{7,118}$ This pathology, which has been described as a rare clinical manifestation of $M$. perstans infections caused by adult $M$. perstans migrating to the eye, is commonly referred to as "bulge" or "bung" eye disease. ${ }^{7,118}$ Whether, however, this pathology is caused by $M$. perstans or a zoonotic parasite from the Mansonella genus is not presently clear. ${ }^{7,118}$ Certainly, it is not uncommon for zoonotic filarial infections to have ocular clinical manifestations of this type. ${ }^{7,8}$ 
In addition to showing that $M$. ozzardi infections are associated with joint pain, leg chills, headaches, and corneal lesions, epidemiological studies have also added support to the notion that $M$. ozzardi infections are mostly asymptomatic. ${ }^{101-105}$ Case reports from tourist-acquired infections have also suggested that $M$. ozzardi infections can cause fatigue, respiratory problems, dermal swellings, and itching; however, evidence that such symptoms occur regularly in endemic settings is still lacking. ${ }^{19,95}$

There have been very few studies of $M$. streptocerca infections. From what data are available, however, it is clear that infections with this parasite are very often (if not exclusively) asymptomatic. 4,5,21,22,25,75 However, it has been proposed that infections cause various types of dermatological symptoms in the shoulders and thorax, where the parasite is mostly encountered. ${ }^{4,5,21,22,25,75}$ Hyperpigmented macules have been attributed to infections occurring in the Democratic Republic of the Congo, but have not been reported everywhere the parasite is found, including Uganda, and thus some authors have cautioned against their attribution to M. streptocerca infections..$^{21,22,75}$ Chronic papular dermatitis has been encountered in most $M$. streptocerca-endemic areas and has been reported to be cleared from patients successfully treated for M. streptocerca infections. ${ }^{75}$ However, in endemic areas where epidemiological studies have been performed, chronic papular dermatitis is no more common in those patients who have detectable $M$. streptocerca in their skin snips than in those that do not, and thus at present there is no statistically robust evidence to support the parasites causing any symptoms at all. $4,5,21,22,25,75$

\section{Diagnosis}

\section{Clinical diagnosis}

As indicated in the previous section, very few clinical symptoms have been robustly linked to mansonellosis in general, ${ }^{4,5,25}$ and at present there is robust evidence to support the notion that only $M$. ozzardi infections cause any clinical symptoms at all. ${ }^{103,104}$ Therefore, it is near impossible to make a reliable clinical diagnosis of mansonellosis, even for M. ozzardi-caused mansonellosis. This is because most of the symptoms that have statistically robust associations with mansonellosis, such as joint pain, are so aspecific, difficult to score, and caused by numerous other pathogens that occur in mansonellosis endemic region as to be of almost no utility at all. ${ }^{101-103}$ Even the potential of corneal lesions for clinical diagnosis is limited, because although they are quite a perceptible physical symptom, they are quite aspecific, occurring in both infected and uninfected individuals from
M. ozzardi-endemic areas. Furthermore, corneal lesions are not manifest in everyone who is infected or even occur everywhere that $M$. ozzardi occurs (eg, there are no reports of $M$. ozzardi causing corneal lesions anywhere in the Caribbean area). ${ }^{103,104}$ In summary, it is presently impossible to use the clinical presentation of mansonellosis to make a reliable diagnosis of the disease.

\section{Parasitological diagnosis}

Traditional parasitological diagnosis, which is based on direct observation of a causative parasite, is still the most common way mansonellosis infections are diagnosed. It is performed by the detection and identification of sheathless Mansonella microfilariae in the skin or blood at any time of day or night. ${ }^{4,5,18,25,30}$ Detection of skin-dwelling microfilariae is usually done by examination of $\sim 1.5 \mathrm{mg}(\sim 2 \mathrm{~mm}$ diameter) skin-biopsy (skin-snip) samples, taken with a Walser or Holth corneoscleral punch. ${ }^{4,5,18,25,30,119}$ The skin-snip test requires that a skin biopsy be taken from areas of presumed optimal microfilariae density, and this varies depending on geographic location. Blood samples used for mansonellosis diagnosis are often taken from peripheral blood samples by way of finger pricks, although venous blood samples can also be used for this purpose. ${ }^{4,5,18,25,30,119}$

When microfilariae are present in high numbers in the patient's blood, as is often the case in endemic areas, they may be easily found and identified in thick or thin blood smears stained with Giemsa or hematoxylin. ${ }^{5,25,30,119}$ Skin snips are usually incubated in water or saline, and the emergent microfilariae can be stained on microscope slides, but in fresh unstained wet preparations of skin snips, the way in which the microfilariae move can also help with their identification. The main diagnostic microfilariae characteristics can be found in Table $1 .^{25,29,30,38,119}$ Morphologically, the most important features to identify microfilariae in blood smears stained with Giemsa are size and shape of the tail, presence or absence of a sheath, and the arrangement of terminal nuclei (in the tail)..$^{18,25,30,38,119}$ All Mansonella microfilariae are unsheathed, and for diagnostic purposes are treated as aperiodic. $5,18,25,30,38,120$

The microfilariae of $M$. perstans are reported to be $200 \times 4-5 \mu \mathrm{m}$, to have blunt rounded tails, and to have nuclei extending to the tips of their tails (Figure 3). M. perstans is easily distinguishable from other blood-dwelling microfilariae, which have overlapping distributions (Loa loa or Wuchereria bancrofti), by their being smaller, their lack of an enveloping sheath, and their tail features (their terminal nuclei are bigger than the other microfilariae). ${ }^{5,18,25,30,119}$ 
A
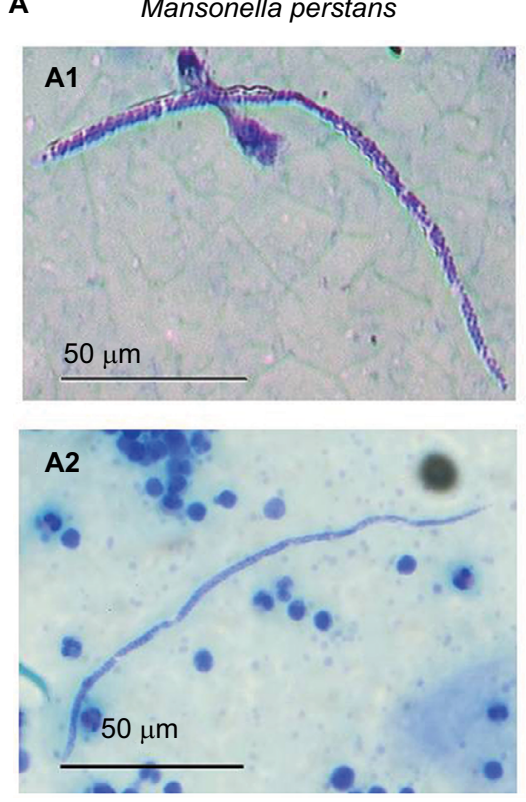

B

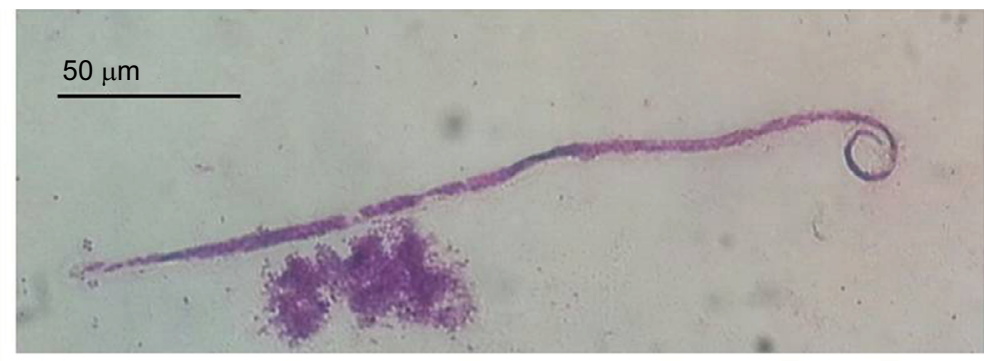

C

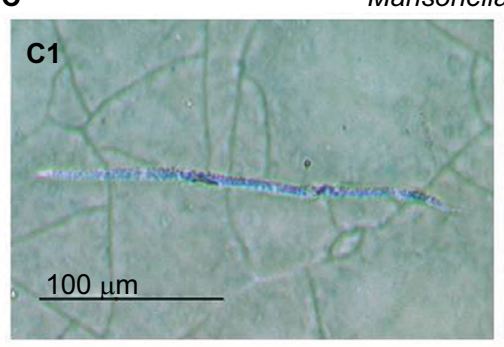

C2

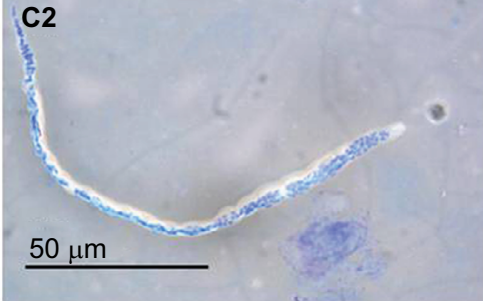

Figure 3 Comparison of the three agents causing mansonellosis illustrating the morphological characteristic of each microfilariae.

Notes: (A) M. perstans microfilariae seen in Giemsa-stained thick blood smear with blunt rounded tail and nuclei extending to the tip of the tail: $M$. perstans parasite from São Gabriel da Cachoeira (Amazonas state, Brazil) (Al); African M. perstans (A2). (B) M. streptocerca microfilariae from a skin-snip fixed and Giemsa-stained showing the characteristic hooked tail. (C) M. ozzardi microfilariae from São Gabriel da Cachoeira (Amazonas state, Brazil) stained with Giemsa (CI, C2).

M. streptocerca microfilariae are smaller and thinner (180-240×3-5 $\mathrm{mm}$ ) than Onchocerca volvulus, and have hook-shaped tails with nuclei that extend to the end (no nuclei are seen in the pointed tail region of $O$. volvulus microfilariae) (Figure 3). 5,18,25,30,119 In wet mounts, live M. streptocerca microfilariae are usually less motile than those of $O$. volvulus. ${ }^{5,119}$ With these morphological descriptions, the two filariae should be easily distinguished. In the past, however, in some countries, such as Uganda, $M$. streptocerca and $O$. volvulus have been confused, despite the clear morphological differences between them. . $^{30,39,75}$

The microfilariae of $M$. ozzardi are reported to be 163 $203 \times 3-5 \mu \mathrm{m}$, with long thin pointed tails and body nuclei that do not extend to the tips of their tails..$^{2-5,30,38}$ As they can locate in both the blood and skin, from a public health perspective it is most important that the microfilariae can be differentiated from $W$. bancrofti and O. volvulus..$^{2-5,25,30,38,119-122}$ The microfilariae of $M$. ozzardi can be easily distinguished from those of $W$. bancrofti by virtue of being smaller and having no sheath (Figure 3). 5,18,25,30,120 Living microfilariae of $M$. ozzardi can be obtained from skin snips and are not easily differentiated from O. volvulus by movement. ${ }^{2-5,25,30,38,119-122}$ Their morphology is similar to the pathogenic $O$. volvulus, and it is especially important to distinguish these two species where they are sympatric, eg, in Amazonia onchocerciasis focus. Although morphological characters can be used to discriminate these two species, ${ }^{38}$ difficulties have led to false reports of new onchocerciasis foci and continue to pose a problem for onchocerciasis epidemiological monitoring in the Amazonia focus, which is now the last Latin America onchocerciasis focus where transmission is considered to be ongoing. ${ }^{30,38,40,99,123,124}$

\section{Inmunodiagnosis}

Immunological methods involve detection of either antibody or antigen. When a filarial parasite immunodiagnostic assay is detecting antibodies, enhanced specificity is often achieved by assessment of IgG4 rather than total IgG, as IgG4 antibodies are significantly elevated in microfilaria-positive individuals. ${ }^{125}$ Although there is presently no effective antigen- or antibody-detecting immunological assay for diagnosis or epidemiological monitoring of mansonellosis infections, both kinds of tools have been developed for onchocerciasis and lymphatic filariasis disease-control programs, and have been tested for cross-reactivity with mansonellosis sera. ${ }^{4,25,51,126-128}$ The reliability (specificity and sensitivity) of these immunodiagnostic tools for lymphatic filariasis and onchocerciasis has not been fully characterized for all of the tests, and the best-understood and most reliable tests are not necessarily the most convenient, and thus whether they should be employed to assist with mansonellosis research and diagnostics is questionable. ${ }^{4,51,124,126-128}$ However, two recently published $M$. perstans studies used generic immunological filariasis assays to support light-microscopy-based diagnoses. ${ }^{116}$ 


\section{Molecular diagnosis}

Although DNA-based diagnostic tools can be used to detect and identify all of the known human filarial parasites, their most important utility to public health is their ability to differentiate skin infections of $M$. streptocerca and $M$. ozzardi from $O$. volvulus skin infections and $M$. perstans parasitemias from L. loa and $W$. bancrofti parasitemias. ${ }^{51,126}$ DNA-based techniques for filarial parasite detection and identification have been proven to be both sensitive and specific, and have now begun to replace light-based microscopy in epidemiological surveys of mansonellosis. ${ }^{4,49,51,52,114,129-133}$ Molecular diagnosis may be used to detect microfilariae in both peripheral blood and skin biopsies, and adult worms in other tissues. ${ }^{4,51,52,114,129}$ PCR-based amplification of species-specific target sequences allows increasing diagnostic sensitivity compared with microscopic methods and reliable differentiation of samples taken from individuals living in coendemic areas. ${ }^{51,52,114,127}$ In 2010, Tang et $\mathrm{al}^{53}$ developed a popular nested PCR that could detect any form and life stage of filariae in the human host or vector. This assay uses universal filariae PCR primers to amplify a variable portion of filarial parasite ribosomal ITS1 DNA, and allows for the subsequent identification of species based on the size of the amplified fragment. This technique is used in conjunction with gel electrophoresis and/ or Sanger sequencing, and allows for the characterization of previously unknown species (the M. perstans variant Deux was found in this way). ${ }^{49,53,114,129}$ Recently, this rDNA ITS1based method was turned into a single-step diagnostic by adapting it for real-time PCR. ${ }^{113,131}$ This new assay allows for the identification of filarial parasite without the need for gel electrophoresis or Sanger sequencing, but does require more expensive reagents and infrastructure than standard PCR assays, and does not directly allow for the characterization of novel or unexpected filarial species. ${ }^{113,131}$ Other methods (such as PCR-restriction-fragment-length polymorphism [RFLP]) that do not allow for the characterization of novel or unexpected filarial species, but require less infrastructure to support them and can differentiate a broad range of filarial species using universal primers with a combination of PCR and RFLP, have also been reported. ${ }^{132,133}$ Despite requiring less complex infrastructural support than alternative methods, PCR-RFLP assays still require access to PCR reagents and a PCR machine, which can be a limiting factor for filarial parasite epidemiological studies.

Last year, the first DNA-detecting loop-mediated isothermal amplification (LAMP) filarial parasite assays were reported. ${ }^{134,135}$ Although these assays have not yet been rigorously tested in the field or developed for the detection of Mansonella parasites, there is no theoretical reason they could not be adapted for mansonellosis research. ${ }^{134,135}$ Requiring almost no infrastructural support, LAMP assays are a particularly appealing diagnostics option for research studies that need to be done in resource-limited settings. ${ }^{51,134,135}$ For this reason, these new LAMP assays can be seen as a welcome development for filarial parasite research in general and an interesting new tool of research to develop for mansonellosis. ${ }^{51,134,135}$

\section{Treatment}

Among the three types of human mansonellosis, the one caused by $M$. perstans is usually regarded as the most difficult to treat. ${ }^{4,18,23,25,116}$ Treatment studies have provided conflicting results, and there are at present no international guidelines on best treatment. ${ }^{18,23,25,67,116,136-140}$ Few studies have recruited sufficient patients to provide statistically robust results to support their conclusions, and many are based on the treatment of one or two European or North American expatriates or tourists returning from endemic areas, who may not respond to treatments in the same way as residents of endemic areas. ${ }^{4,23,25,116}$ The existence of genetically distinct strains of M. perstans (like Deux or strains that lack Wolbachia) complicates the formulation of treatment guidelines further, as it also possible that the efficacy of therapeutics varies between these strains. ${ }^{60,66}$

In one of the more robust $M$. perstans mansonellosis studies hitherto, conducted in the south of Chad, symptomatic subjects with evidence of $M$. perstans microfilariae in the peripheral blood were divided in groups and tested with the antiparasitic drugs diethylcarbamazine (DEC), mebendazole, ivermectin, praziquantel, thiabendazole, and DEC plus mebendazole. ${ }^{137} \mathrm{DEC}$ plus mebendazole proved to be the most effective antiparasitic treatment to reduce microfilaremia, and it is now one of the most used. Thiabendazole was second, with a single treatment significantly reducing microfilariae in blood. Ivermectin and praziquantel did not prove to be useful in the treatment of M. perstans infections. Mebendazole alone was seen to be a good alternative treatment and appeared to be more active than DEC alone in eliminating the infection. ${ }^{137}$

In another study carried out in Uganda, ivermectin alone, albendazole alone, and the two drugs in combination were assessed in three groups infected with M. perstans. ${ }^{138}$ In this study, in concordance with the aforementioned study, microfilarial levels were unaffected by ivermectin or albendazole treatment when these drugs were used alone. Van den Enden et al ${ }^{136}$ reached the same conclusion about albendazole treatment after finding that treatment had not decreased 
microfilarial counts after a median follow-up period of 45 days. However, it has been found that when these drugs (ivermectin + albendazole) are used in combination, microfilarial loads decrease slightly after treatment. ${ }^{136,139}$

In contrast to conventional anthelmintic treatments, doxycycline has proved to be excellent, effective, and safe in the treatment of $M$. perstans infections. ${ }^{4,67,116,139,140}$ However, the course of treatment over 6 weeks, which is necessary for this type of therapy, probably makes it impractical for control programs, although the fact that it appears to be curative makes it a very desirable therapeutic for travel medicine., ${ }^{4,65,67}$ However, doxycycline treatment may not work on all $M$. perstans infections, as there is evidence of subspecies genetic diversity among $M$. perstans parasites and it is presently unclear whether all M. perstans strains harbor the Wolbachia endosymbiont. ${ }^{60,66}$ This treatment's safety profile and all hitherto-published results on its efficacy, however, suggest that doxycycline treatment should be the first-choice treatment for perstans mansonellosis wherever it can be feasibly administered. . $^{7,115,116}$

The use of ivermectin for treating $M$. ozzardi has proven to be very effective against microfilariae in a number of studies. ${ }^{3,23,25,29,139-143}$ A single dose of ivermectin given to infected adults was seen to reduce microfilariae densities and provide both short- and long-term reductions in M. ozzardi microfilaraemia. ${ }^{29,142,143}$ Adverse events, however, have been seen in some patients with $M$. ozzardi treated with ivermectin. ${ }^{143}$ Two elderly patients from Argentina developed serious adverse events that resembled a Mazzotti reaction following ivermectin administration, although the patients recovered without sequelae after $2-3$ days. ${ }^{143}$ DEC has little or no effect on microfilariae of $M$. ozzardi.

Because of its effectiveness in the treatment of $M$. ozzardi, ivermectin has been used as a mansonellosis control tool in the Brazilian Amazon region. ${ }^{139,140}$ The recent discovery of M. perstans in the northern regions of the Brazilian Amazon, however, suggests that this approach will not be effective everywhere. ${ }^{50}$ As $M$. ozzardi are also known to harbor the endosymbiotic Wolbachia, it maybe that mansonellosis in this region can be tackled with a single anti-Wolbachia treatment regime using an antibacterial agent. ${ }^{3,4,144}$ Although the six-week treatment course required for doxycycline-based therapies makes them impractical for filarial parasite-control programs, new antiWolbachia therapeutics with far shorter treatment courses (of 3-7 days) are in the pipeline and could make appealing treatment options throughout the whole Amazon region and beyond. ${ }^{145-148}$ However, it is important that before such a measure is employed, efforts are made to determine whether this treatment interrupts transmission (like ivermectin treatment does). This is important to establish, as anti-Wolbachia treatments are not thought to kill Mansonella microfilariae directly and may thus not interrupt mansonellosis transmission as effectively as some of the alternative options. ${ }^{67,115,117}$

DEC and ivermectin have been used with good effect to treat $M$. streptocerca infection. ${ }^{4,18,25,39,149}$ Fischer et al found that a single dose of $150 \mu \mathrm{g} / \mathrm{kg}$ body weight of ivermectin suppresses microfilaria for a year or more, with $46 \%$ of individuals displaying no detectable microfilaria on skin biopsy 1 year after treatment. ${ }^{149}$ The most common treatment for $M$. streptocerca infections is DEC given at $6 \mathrm{mg} / \mathrm{kg} /$ day orally in three doses for 12 days. ${ }^{139,140}$ At present, it is unclear whether M. streptocerca harbors a Wolbachia endosymbiont like $M$. ozzardi and M. perstans. ${ }^{4,66}$ If it does, the possibility of using an anti-Wolbachia therapeutic like doxycycline for the treatment of $M$. streptocerca should also be investigated. ${ }^{4,139,140}$

\section{Global burden}

The high prevalence of asymptomatic cases and the lack of a universally agreed clinical profile for any of the three forms of mansonellosis infection has left many researchers in the field reluctant to even describe mansonellosis as a disease, with some authors conspicuously avoiding the word "disease" and some preferring to use the term "condition". ${ }^{1-5,18,25}$ This prevailing perspective of mansonellosis as a benign parasitic infection with little or no direct effect on patients' well-being has left mansonellosis research trapped in a vicious circle of neglect. Mansonellosis research is unable to generate robust clinical data exactly because of the present paucity of robust clinical data makes funding mansonellosis research difficult for research councils to justify.

In addition to this, the symptoms currently directly attributed to mansonellosis are difficult to utilize in the modern metric systems used to assess disease burden and in the allocation of research funding. From the data presently available, it is impossible to assign any mortalities directly to mansonellosis infection and even difficult to assign the disability-adjusted life-years or years lost to disability, which have been used so effectively in the advocacy of attracting research funding to the 13 core neglected tropical diseases. ${ }^{150-152}$ Recent surveys of the global burden of disease commissioned by a major tropical disease research fund have omitted mansonellosis from their analyses, which has surely resulted in the disease receiving a neglect that may be inappropriate. ${ }^{151-154}$

Even without a recognized disease burden, however, it is still clear that mansonellosis has an important role in 
global health by indirectly interfering with the effectiveness of control programs targeting more serious diseases. ${ }^{4,29,53}$ As mentioned earlier, the similarity between the microfilariae of O. volvulus with $M$. streptocerca (in Africa) and M. ozzardi (in Latin America) encountered in skin snips has led to false reports of onchocerciasis foci and misallocation of precious onchocerciasis-control resources. ${ }^{39,40,120}$ Although we are unaware of published accounts of $M$. perstans in skin being confused with $O$. volvulus, the recent molecular detection of M. perstans DNA in skin snips on the island of Bioko (Equatorial Guinea) suggests that it could potentially have happened without being detected. ${ }^{113}$ Similarly, mansonellosis parasites have been shown to interfere with some onchocerciasis immunodiagnostic assays and are suspected of interfering with the reliability of others..$^{51,120,124}$ In relation to lymphatic filariasis control, false-positive results with the Binax Now filariasis immunochromatographic test have recently been recorded in several independent studies carried out in central Africa. It is presently argued that the observed cross-reactivity is entirely attributable to L. loa infections, but a role for M. perstans in cross-reactivity has not yet been definitively ruled out. ${ }^{128,151,152}$

Beyond mansonellosis's direct and indirect (by raising morbidity in coinfection cases) disease burden and beyond even its role in interfering with the diagnostics used in other neglected tropical disease-control planning, it could also be negatively affecting global health by negatively impacting the efficacy of vaccine programmes. ${ }^{154-156}$ It has been shown, for example, that certain lymphatic filariasis infections can affect the efficacy of some vaccines (including tuberculosis and HIV vaccines), and thus it is quite possible that mansonellosis infections could have a similar effect. ${ }^{156}$ For this reason, some authors have discussed the possibility of auxiliary "deworming" programs to accompany vaccine programs as a way of potentially improving their efficacy. ${ }^{154-156}$ Given the importance of vaccines as tools for infectious disease control and the extremely high prevalence of mansonellosis in infectious disease hot spots, the influence mansonellosis has on the efficacy of vaccine programs may in fact be the most important impact mansonellosis has on global health. ${ }^{154-156}$

\section{Disclosure}

The authors report no conflicts of interest in this work.

\section{References}

1. Downes BL, Jacobsen KH. A systematic review of the epidemiology of mansonelliasis. Afr J Infect Dis. 2010;4(1):7-14.

2. Bain O, Mutafchiev Y, Junker K, et al. Review of the genus Mansonella Faust, 1929 sensu lato (Nematoda: Onchocercidae), with descriptions of a new subgenus and a new subspecies. Zootaxa. 2015;3918(2):151-193.
3. Lima NF, Aybar CA, Juri MJ, Ferreira MU. Mansonella ozzardi: a neglected New World filarial nematode. Pathog Glob Health. 2016;110(3):97-107.

4. Medeiros JF, Crainey JL, Pessoa FA, Luz SL. Mansonelliasis. In: Marcondes CB, editor. Arthropod Borne Diseases. Heidelberg: Springer; 2017:405-426.

5. Nutman TB. Filarial infections. In: Cohen J, Powderly WG, Opal SM, editors. Infectious Diseases. Amsterdam: Elsevier; 2016:1046-1052.

6. Richard-Lenoble D, Kombila M, Bain O, Chandenier J, Mariotte O. Filariasis in Gabon: human infections with Microfilaria rodhaini. Am J Trop Med Hyg. 1988;39(1):91-92.

7. Orihel TC, Eberhard ML. Zoonotic filariasis. Clin Microbiol Rev. 1998;11(2):366-381.

8. Otranto D, Eberhard ML. Zoonotic helminths affecting the human eye. Parasit Vectors. 2011;4:41.

9. Sucharit S. Mansonella infecting man in Thailand. J Med Assoc Thai. 1988;71(10):587-588.

10. Raccurt CP. Mansonella ozzardi and its vectors in the New World: an update with emphasis on the current situation in Haiti. J Helminthol. Epub 2017 Oct 25.

11. Nelson GS. Filarial infections as zoonoses. J Helminthol. 1965; 39(2):229-250.

12. Marinkelle CJ, German E. Mansonelliasis in the Comisaria del Vaupes of Colombia. Trop Geogr Med 1970;22(1):101-111.

13. Neafie R, Meyers W, Connor DJ. Mansonelliasis. In: Binford C, Connor D, editors. Pathology of Tropical and Extraordinary Diseases. Washington: Armed Forces Institute; 1976:390.

14. Shelley AJ, Dias AP, Moraes MA. Simulium species of the amazonicum group as vectors of Mansonella ozzardi in the Brazilian Amazon. Trans R Soc Trop Med Hyg. 1980;74(6):784-788.

15. Linley JR, Hoch AL, Pinheiro FP. Biting midges (Diptera: Ceratopogonidae) and human health. J Med Entomol. 1983:20(4):347-364.

16. Eberhard ML, Orihel TC. The genus Mansonella (syn. Tetrapetalonema): a new classification. Ann Parasitol Hum Comp. 1984;59(5): 483-496.

17. Orihel TC, Eberhard ML. Mansonella ozzardi: a redescription with comments on its taxonomic relationships. Am JTrop Med Hyg. 1982;31(6): 1142-1147.

18. Muller R. Worms and Human Disease. 2nd ed. Wallingford, UK: CABI International; 2002.

19. Nutman TB, Nash TE, Ottesen EA. Ivermectin in the successful treatment of a patient with Mansonella ozzardi infection. J Infect Dis. 1987;156(4):662-665.

20. Kozek WJ, D’Alessandro A, Silva J, Navarette SN. Filariasis in Colombia: prevalence of mansonellosis in the teenage and adult population of the Colombian bank of the Amazon, Comisaria del Amazonas. Am J Trop Med Hyg. 1982;31(6):1131-1136.

21. Meyers WM, Connor DH, Harman LE, Fleshman K, Moris R, Neafie RC. Human streptocerciasis: a clinico-pathologic study of 40 Africans (Zairians) including identification of the adult filaria. Am J Trop Med Hyg. 1972;21(5):528-545.

22. Duke BO. A case of streptocerciasis in a European. Ann Trop Med Parasitol. 1957;51(4):364-367.

23. Simonsen PE, Onapa AW, Asio SM. Mansonella perstans filariasis in Africa. Acta Trop. 2011;120 Suppl 1:S109-S120.

24. Bassene H, Sambou M, Fenollar F, et al. High prevalence of Mansonella perstans filariasis in rural Senegal. Am J Trop Med Hyg. 2015;93(3):601-606.

25. Simonsen PE, Fischer PU, Hoerauf A, Weil GJ. The filariasis. In: Farrar J, Hotez PJ, Junghanss T, Kang G, Lalloo D, White NJ, editors. Manson's Tropical Diseases. 23rd ed. London: Saunders; 2014:737-765.

26. Lane RP, Crosskey RW. Medical Insects and Arachnids. Heidelberg: Springer Netherlands; 1993.

27. Crosskey RW. The Natural History of Blackflies. Chichester, UK: Wiley; 1990.

28. Orihel TC, Lowrie RC Jr, Eberhard ML, et al. Susceptibility of laboratory primates to infection with Mansonella ozzardi from man. Am J Trop Med Hyg. 1981;30(4):790-794. 
29. Shelley AJ, Coscaron S. Simuliid blackflies (Diptera: Simuliidae) and ceratopogonid midges (Diptera: Ceratopogonidae) as vectors of Mansonella ozzardi (Nematoda: Onchocercidae) in northern Argentina. Mem Inst Oswaldo Cruz. 2001;96(4):451-458.

30. World Health Organization. Bench Aids for the Diagnosis of Filarial Infections. Geneva: WHO; 1997.

31. Pichon G. Crypto-periodicity in Mansonella ozzardi. Trans R Soc Trop Med Hyg. 1983;77(3):331-333.

32. Sharp NA. Filaria perstans: its development in Culicoides austeni. Trans R Soc Trop Med Hyg. 1928:21:371-396.

33. Manson P. On certain new species of nematode haematozoa occurring in America. Br Med J. 1897:2:1837-1838.

34. Godoy GA, Orihel TC, Volcan GS. Microfilaria bolivarensis: a new species of filaria from man in Venezuela. Am J Trop Med Hyg 1980;29(4):545-547.

35. Adami YL, Moraes MA, Lanfredi RM, Maia-Herzog M. An atypical microfilaria in blood samples from inhabitants of Brazilian Amazon. Parasitol Res. 2008;104(1):95-99.

36. Arrospide N, Adami YL, Gutierrez S, Vargas J. [Morphological characterization of atypical and ozzardi microfilariae of Mansonella gender] Rev Peru Med Exp Salud Publica. 2012;29(1):161-163. Spanish.

37. Medeiros, Costa FA, Martins M. The importance of thick blood film method for sympatric filarial diagnosis in Amazon basin. Acta Amazon. 2010;40(4):779-780.

38. Post RJ, Adams Z, Shelley AJ, Maia-Herzog M, Dias AP, Coscarón S. The morphological discrimination of microfilariae of Onchocerca volvulus from Mansonella ozzardi. Parasitology. 2003;127(Pt 1):21-27.

39. Fischer P, Bamuhiiga J, Büttner DW. Treatment of human Mansonella streptocerca infection with ivermectin. Trop Med Int Health. 1997;2(2):191-199.

40. Moraes MA, Almeida MM, Lovelace JK, Chaves GM. [Mansonella ozzardi among Ticuna Indians of the state of Amazonas, Brazil]. Bol Oficina Sanit Panam. 1978;85(1):16-25. Portuguese.

41. Dukes DC, Gelfand M, Gadd KG, Clarke VD, Goldsmid JM. Cerebral filariasis caused by Acanthocheilonema perstans. Cent Afr J Med. 1968;14(2):21-27.

42. Holmes GK, Gelfand M, Boyt W, Mackenzie P. A study to investigate the pathogenicity of a parasite resembling Acanthocheilonema perstans. Trans R Soc Trop Med Hyg. 1969;63(4):479-484.

43. Orihel TC, Esslinger JH. Meningonema peruzzii gen. et sp. n. (Nematoda: Filarioidea) from the central nervous system of African monkeys. J Parasitol. 1973;59(3):437-441.

44. Rubin RH, Austen KF, Goetzl EJ. Studies of immediate hypersensitivity in a patient with Acanthocheilonema perstans filarial infection. J Infect Dis. 1975;131 Suppl:S98-S103.

45. Sondergaard J. Filariasis caused by Acanthocheilonema perstans. Arch Dermatol 1972;106(4):547-548.

46. Berkowitz AL, Raibagkar P, Pritt BS, Mateen FJ. Neurologic manifestations of the neglected tropical diseases. J Neurol Sci. 2015;349(1-2) 20-32.

47. Fux CA, Chappuis B, Holzer B, et al. Mansonella perstans causing symptomatic hypereosinophilia in a missionary family. Travel Med Infect Dis. 2006;4(5):275-280.

48. Marcos LA, Arrospide N, Recuenco S, Cabezas C, Weil GJ, Fischer PU. Genetic characterization of atypical Mansonella (Mansonella) ozzardi microfilariae in human blood samples from northeastern Peru. Am J Trop Med Hyg. 2012;87(3):491-494.

49. Ta-Tang TH, Luz SL, Merino FJ, et al. Atypical Mansonella ozzardi microfilariae from an endemic area of Brazilian Amazonia. Am J Trop Med Hyg. 2016;95(3):629-632.

50. da Silva LB, Crainey JL, da Silva TR, et al. Molecular verification of New World Mansonella perstans Parasitemias. Emerg Infect Dis. 2017;23(3): 545-547.

51. Alhassan A, Li Z, Poole CB, Carlow CK. Expanding the MDx toolbox for filarial diagnosis and surveillance. Trends Parasitol. 2015;31(8):391-400.
52. Ricciardi A, Ndao M. Diagnosis of parasitic infections: what's going on? J Biomol Screen. 2015;20(1):6-21.

53. Tang TH, Lopez-Velez R, Lanza M, Shelley AJ, Rubio JM, Luz SL. Nested PCR to detect and distinguish the sympatric filarial species Onchocerca volvulus, Mansonella ozzardi and Mansonella perstans in the Amazon region. Mem Inst Oswaldo Cruz. 2010;105(6):823-828.

54. Morales-Hojas R, Cheke RA, Post RJ. A preliminary analysis of the population genetics and molecular phylogenetics of Onchocerca volvulus (Nematoda: Filarioidea) using nuclear ribosomal second internal transcribed spacer sequences. Mem Inst Oswaldo Cruz. 2007;102(7):879-882.

55. Morales-Hojas R, Cheke RA, Post RJ. Molecular systematics of five Onchocerca species (Nematoda: Filarioidea) including the human parasite, $O$. volvulus, suggest sympatric speciation. $J$ Helminthol. 2006;80(3):281-290.

56. Morales-Hojas R, Post RJ, Shelley AJ, Maia-Herzog M, Coscarón S, Cheke RA. Characterisation of nuclear ribosomal DNA sequences from Onchocerca volvulus and Mansonella ozzardi (Nematoda: Filarioidea) and development of a PCR-based method for their detection in skin biopsies. Int J Parasitol. 2001;31(2):169-177.

57. Xie H, Bain O, Williams SA. Molecular phylogenetic studies on filarial parasites based on 5S ribosomal spacer sequences. Parasite. 1994;1(2):141-151.

58. Lefoulon E, Bain O, Bourret J, et al. Shaking the tree: multi-locus sequence typing usurps current onchocercid (filarial nematode) phylogeny. PLoS Negl Trop Dis. 2015;9(11):e0004233.

59. Morales-Hojas R. Molecular systematics of filarial parasites, with an emphasis on groups of medical and veterinary importance, and its relevance for epidemiology. Infect Genet Evol. 2009;9(5):748-759.

60. Mourembou G, Fenollar F, Lekana-Douki JB, et al. Mansonella, including a potential new species, as common parasites in children in Gabon. PLoS Negl Trop Dis. 2015;9(10):e0004155.

61. McGarry HF, Pfarr K, Egerton G, et al. Evidence against Wolbachia symbiosis in Loa loa. Filaria J. 2003;2(1):9.

62. Ferri E, Bain O, Barbuto M, et al. New insights into the evolution of Wolbachia infections in filarial nematodes inferred from a large range of screened species. PLoS One. 2011;6(6):e20843.

63. Casiraghi M, Bain O, Guerrero R, et al. Mapping the presence of Wolbachia pipientis on the phylogeny of filarial nematodes: evidence for symbiont loss during evolution. Int J Parasitol. 2004;34(2):191-203.

64. Nikoh N, Hosokawa T, Moriyama M, Oshima K, Hattori M, Fukatsu T. Evolutionary origin of insect-Wolbachia nutritional mutualism. Proc Natl Acad Sci U S A. 2014;111(28):10257-10262.

65. Taylor MJ, Hoerauf A, Bockarie M. Lymphatic filariasis and onchocerciasis. Lancet. 2010;376(9747):1175-1185.

66. Gehringer C, Kreidenweiss A, Flamen A, Antony JS, Grobusch MP, Bélard S. Molecular evidence of Wolbachia endosymbiosis in Mansonella perstans in Gabon, central Africa. J Infect Dis. 2014;210(10):1633-1638.

67. Coulibaly YI, Dembele B, Diallo AA, et al. A randomized trial of doxycycline for Mansonella perstans infection. $N$ Engl $J$ Med. 2009;361(15):1448-1458.

68. Büttner DW, Wanji S, Bazzocchi C, Bain O, Fischer P. Obligatory symbiotic Wolbachia endobacteria are absent from Loa loa. Filaria J 2003;2(1): 10

69. Grobusch MP, Kombila M, Autenrieth I, Mehlhorn H, Kremsner PG. No evidence of Wolbachia endosymbiosis with Loa loa and Mansonella perstans. Parasitol Res. 2003;90(5):405-408.

70. Van de PeerY, De Wachter R. Treecon for Windows: a software package for the construction and drawing of evolutionary trees for the Microsoft Windows environment. Comput Appl Biosci. 1994;10(5):569-570.

71. Crainey JL, da Silva TR, Luz SL. Historic accounts of Mansonella parasitaemias in the South Pacific and their relevance to lymphatic filariasis elimination efforts today. Asian Pac J Trop Med. 2016;9(3):205-210.

72. Christy C. The distribution of sleeping sickness, Filaria perstans, etc. in East Equatorial Africa. Rep R Soc Sleep Sickn Comm. 1903;2:2-8. 
73. Bastian HC. Note on the probable mode of infection by the so-called filaria perstans, and on the probability that this organism really belongs to the genus Tylenchus (bastian). Lancet. 1904;163(4196): 286-287.

74. Stensgaard AS, Vounatsou P, Onapa AW, et al. Ecological drivers of Mansonella perstans infection in Uganda and patterns of coendemicity with lymphatic filariasis and malaria. PLoS Negl Trop Dis. 2016;10(1):e0004319.

75. Fischer P, Bamuhiiga J, Büttner DW. Occurrence and diagnosis of Mansonella streptocerca in Uganda. Acta Trop. 1997;63(1):43-55.

76. Bamuhiiga JT. Mansonella streptocerca: another filarial worm in the skin in Western Uganda. Community Eye Health. 1998;11(26):28.

77. Duke BO. The uptake of the microfilariae of Acanthocheilonema streptocerca by Culicoides grahamii, and their subsequent development. Ann Trop Med Parasitol. 1954;48(4):416-420.

78. Duke BO. The intake of the microfilariae of Acanthocheilonema streptocerca by Culicoides milnei, with some observations on the potentialities of the fly as a vector. Ann Trop Med Parasitol. 1958;52(2):123-128.

79. Shelley AJ, Hernandez LM, Maia-Herzog M. The blackflies (Diptera: Simuliidae) of Brazil. In: Arias JR, Golovatch S, Wantzen KM, Dominguez E, editors. Aquatic Biodiversity in Latin America. Sofia: Pensoft; 2010;6:821.

80. Yarzábal L, Basáñez MG, Ramírez-Pérez J, Ramírez A, Botto C, Yarzábal A. Experimental and natural infection of Simulium sanchezi by Mansonella ozzardi in the Middle Orinoco region of Venezuela. Trans R Soc Trop Med Hyg. 1985;79(1):29-33.

81. Tidwell MA, Tidwell MA. Development of Mansonella ozzardi in Simulium amazonicum, S. argentiscutum, and Culicoides insinuatus from Amazonas, Colombia. Am J Trop Med Hyg. 1982;31(6): 1137-1141.

82. Tidwell MA, Tidwell MA, Muñoz de Hoyos P. Development of Mansonella ozzardi in a black fly species of the Simulium sanguineum group from eastern Vaupés, Colombia. Am J Trop Med Hyg. 1980;29(6):1209-1214.

83. US Centers for Disease Control and Prevention. DPDX: laboratory identification of parasitic diseases of public health concern. 2017. Available from: http:/www.dpd.cdc.gov/dpdx. Accessed November 28, 2017.

84. Shelley AJ, Shelley A. Further evidence for the transmission of Mansonella ozzardi by Simulium amazonicum in Brazil. Ann Trop Med Parasitol. 1976;70(2):213-217.

85. Lowrie RC Jr, Raccurt CP, Eberhard ML, Katz SP. Assessment of Leptoconops bequaerti as a potential vector of Mansonella ozzardi in Haiti. Am J Trop Med Hyg. 1983;32(5):1013-1015.

86. Lowrie RC Jr, Raccurt CP. Assessment of Culicoides barbosai as a vector of Mansonella ozzardi in Haiti. Am JTrop Med Hyg. 1984;33(6): 1275-1277.

87. Buckley JJ. On the development, in Culicoides furens Poey, of Filaria (= Mansonella) ozzardi. Manson, 1897. J Helminthol. 1934;12(2):99-118.

88. Nathan MB. Transmission of the human filarial parasite Mansonella Ozzardi by Culicoides phlebotomus (Williston) (Diptera: Ceratopogonidae) in coastal north Trinidad. Bull Entomol Res. 1981;71(1):9 7-106.

89. Cerqueira NL. Sobre a transmissão da Mansonella ozzardi. J Bras Med. 1959;1:885-914.

90. Nelson GS, Pester FR. The identification of infective filarial larvae in Simuliidae. Bull World Health Organ. 1962;27:473-481.

91. Basano SA, Camargo JS, Vera LJ, et al. Investigation of the occurrence of Mansonella ozzardi in the state of Rondonia, western Amazonia, Brazil. Rev Soc Bras Med Trop. 2011;44(5):600-603.

92. Deane MP. Sobre a incidência de filárias humanas em Manaus; Estado do Amazonas. Rev Fund SESP. 1949;2:849-858.

93. Lacerda NB, Rachou RG. Filarioses humanas nas sedes municipais do Estado do Amazonas e territórios do Acre, Guaporé Rio Branco. Rev Bras Malariol D Trop. 1956;8:437-442.
94. Velasques SN, Medeiros JF, Pessoa FA, Julião GR, de Souza CC, Camargo LM. Ocorrência e antropofilia de simulídeos em comunidades ribeirinhas de Rondônia, Brasil. 2012. Available from: http:// www.periodico.ebras.bio.br/ojs/index.php/ebras/article/view/174/164. Accessed November 28, 2017.

95. Weller PF, Simon HB, Parkhurst BH, Medrek TF. Tourism-acquired Mansonella ozzardi microfilaremia in a regular blood donor. JAMA. 1978;240(9):858-859.

96. Charles LJ. Malaria in the Leeward and Windward islands, British West Indies. Am J Trop Med Hyg. 1952;1(6):941-961.

97. Eisenbarth A, Achukwi MD, Renz A. Ongoing transmission of Onchocerca volvulus after 25 years of annual ivermectin mass treatments in the Vina du Nord River Valley, in north Cameroon. PLoS Negl Trop Dis. 2016;10(2):e0004392.

98. Crainey JL, Medeiros JF, Pessoa FA, Luz SL. Onchocerciasis. In: Marcondes CB, editor. Arthropod Borne Diseases. Heidelberg: Springer; 2017:383-403.

99. Silva TR, Crainey JL, Souza HV, et al. Caracterização molecular de nova espécie de Mansonella sp transmitida por vetores antropofílicos da Amazônia brasileira. Poster presented at: 53rd Congress of the Brazilian Society of Tropical Medicine; August 27-30, 2107; Cuiabá, Brazil.

100. Adami YL, Rodrigues G, Alves MC, Moraes MA, Banic DM, MaiaHerzog M. New records of Mansonella ozzardi: a parasite that is spreading from the state of Amazonas to previously uninfected areas of the state of Acre in the Purus River region. Mem Inst Oswaldo Cruz. 2014;109(1):87-92.

101. Martins M, Pessoa FA, de Medeiros MB, de Andrade EV, Medeiros JF. Mansonella ozzardi in Amazonas, Brazil: prevalence and distribution in the municipality of Coari, in the middle Solimões River. Mem Inst Oswaldo Cruz. 2010;105(3):246-253.

102. Medeiros JF, Py-Daniel V, Barbosa UC, Ogawa GM. Current profile of Mansonella ozzardi (Nematoda: Onchocercidae) in communities along the Ituxi river, Lábrea municipality, Amazonas, Brazil. Mem Inst Oswaldo Cruz. 2008;103(4):409-411.

103. Vianna LM, Martins M, Cohen MJ, Cohen JM, Belfort R Jr. Mansonella ozzardi corneal lesions in the Amazon: a cross-sectional study. BMJ Open. 2012;2(6): $\mathrm{e} 001266$.

104. Garrido C, Campos M. First report of presumed parasitic keratitis in Indians from the Brazilian Amazon. Cornea. 2000;19(6):817-819.

105. Medeiros JF, Py-Daniel V, Barbosa UC. Prevalence of Mansonella ozzardi among riverine communities in the municipality of Lábrea, state of Amazonas, Brazil. Rev Soc Bras Med Trop. 2011;44(2): 186-190.

106. Medeiros JF, Py-Daniel V, Barbosa UC, Izzo TJ. Mansonella ozzardi in Brazil: prevalence of infection in riverine communities in the Purus region, in the state of Amazonas. Mem Inst Oswaldo Cruz. 2009;104(1):74-80.

107. Bartoloni A, Cancrini G, Bartalesi F, et al. Mansonella ozzardi infection in Bolivia: prevalence and clinical associations in the Chaco region. Am J Trop Med Hyg. 1999;61(5):830-833.

108. Kozek WJ, Palma G, Henao A, Garcia H, Hoyos M. Filariasis in Colombia: prevalence and distribution of Mansonella ozzardi and Mansonella (=Dipetalonema) perstans infections in the Comisaria del Guainia. Am J Trop Med Hyg. 1983;32(2):379-384.

109. Formica S, Botto C. Filariasis focus due to Mansonella ozzardi and Mansonella perstans in the Amazon federal territory of Venezuela. $J$ Trop Med Hyg. 1990;93(3):160-165.

110. Dolo H, Coulibaly YI, Dembele B, et al. Filariasis attenuates anemia and proinflammatory responses associated with clinical malaria: a matched prospective study in children and young adults. PLoS Negl Trop Dis. 2012;6(11):e1890.

111. Bouyou-Akotet MK, Boussougou MN, Ovono-Abessolo F, OwonoMedang M, Kombila M. Influence of Mansonella perstans microfilaraemia on total IgE levels in Gabonese patients co-infected with Loa loa. Acta Trop. 2014;131:11-15. 
112. Keiser PB, Coulibaly YI, Keita F, et al. Clinical characteristics of post-treatment reactions to ivermectin/albendazole for Wuchereria bancrofti in a region co-endemic for Mansonella perstans. Am J Trop Med Hyg. 2003;69(3):331-335.

113. Moya L, Herrador Z, Ta-Tang TH, et al. Evidence for suppression of onchocerciasis transmission in Bioko Island, Equatorial Guinea. PLoS Negl Trop Dis. 2016;10(7):e0004829.

114. Phillips RO, Frimpong M, Sarfo FS, et al. Infection with Mansonella perstans nematodes in Buruli ulcer patients, Ghana. Emerg Infect Dis. 2014;20(6):1000-1003.

115. Adolph PE, Irving GK, McQuay RM. Diagnosis and treatment of Acanthocheilonema perstans filariasis. Am J Trop Med Hyg. 1962;11(1):76-88.

116. Asgeirsson H, Harling A, Botero-Kleiven S. Successful treatment of 2 imported cases of Mansonella perstans infection. PLoS Negl Trop Dis. 2017;11(5):e0005452.

117. Bregani ER. Filariasis due to blood transfusion. Blood Transfus. 2010;8(2):129.

118. Baird JK, Neafie RC, Connor DH. Nodules in the conjunctiva, bungeye, and bulge-eye in Africa caused by Mansonella perstans. Am J Trop Med Hyg. 1988;38(3):553-557.

119. Rosenblatt JE. Laboratory diagnosis of infections due to blood and tissue parasites. Clin Infect Dis. 2009;49(7):1103-1108.

120. Medeiros JM, Costa FA, Camargo LM. Mansonelliasis: a Brazilian neglected disease. Rev Patol Trop. 2014;43(1):1-6.

121. Ewert A, Smith JH, Corredor A. Microfilariae of Mansonella ozzardi in human skin biopsies. Am J Trop Med Hyg. 1981;30(5):988-991.

122. Moraes MA, Shelley AJ, Dias AP, Silva CJ. The concentration of Mansonella ozzardi microfilariae in skin capillaries. Trans $R$ Soc Trop Med Hyg. 1983;77(4):463-466.

123. Shelley AJ. Human onchocerciasis in Brazil: an overview. Cad Saude Publica. 2002;18(5):1167-1177.

124. Luz SL, Crainey JL, Shelley AJ, Rubio M. Outstanding insecurities concerning the use of an Ov16-based ELISA in the Amazonia onchocerciasis focus. Mem Inst Oswaldo Cruz. 2014;109(4): 506-508.

125. Egwang TG, Nguiri C, Kombila M, Duong TH, Richard-Lenoble D. Elevated antifilarial IgG4 antibody levels in microfilaremic and microfilaridermic Gabonese adults and children. Am J Trop Med Hyg. 1993;49(1):135-142.

126. Walther M, Muller R. Diagnosis of human filariases (except onchocerciasis). Adv Parasitol. 2003;53:149-193.

127. Shelley AJ, Maia-Herzog M, Calvão-Brito R. The specificity of an ELISA for detection of Onchocerca volvulus in Brazil in an area endemic for Mansonella ozzardi. Trans $R$ Soc Trop Med Hyg. 2001;95(2):171-173.

128. Wanji S, Amvongo-Adjia N, Njouendou AJ, et al. Further evidence of the cross-reactivity of the Binax NOW filariasis ICT cards to nonWuchereria bancrofti filariae: experimental studies with Loa loa and Onchocerca ochengi. Parasit Vectors. 2016;9:267.

129. Medeiros JF, Almeida TA, Silva LB, et al. A field trial of a PCR-based Mansonella ozzardi diagnosis assay detects high-levels of submicroscopic $M$. ozzardi infections in both venous blood samples and FTA card dried blood spots. Parasit Vectors. 2015;8:280.

130. Fischer P, Buttner DW, Bamuhiiga J, Williams SA. Detection of the filarial parasite Mansonella streptocerca in skin biopsies by a nested polymerase chain reaction-based assay. Am J Trop Med Hyg. 1998;58(6):816-820.

131. Thiele EA, Cama VA, Lakwo T, et al. Detection of Onchocerca volvulus in skin snips by microscopy and real-time polymerase chain reaction: implications for monitoring and evaluation activities. Am J Trop Med Hyg. 2016;94(4):906-911.

132. Nuchprayoon S, Junpee A, Poovorawan Y, Scott AL. Detection and differentiation of filarial parasites by universal primers and polymerase chain reaction-restriction fragment length polymorphism analysis. $\mathrm{Am}$ J Trop Med Hyg. 2005;73(5):895-900.
133. Jimenez M, Gonzalez LM, Carranza C, et al. Detection and discrimination of Loa loa, Mansonella perstans and Wuchereria bancrofti by PCR-RFLP and nested-PCR of ribosomal DNA ITS1 region. Exp Parasitol. 2011;127(1):282-286.

134. Alhassan A, Osei-Atweneboana MY, Kyeremeh KF, et al. Comparison of a new visual isothermal nucleic acid amplification test with PCR and skin snip analysis for diagnosis of onchocerciasis in humans. Mol Biochem Parasitol. 2016;210(1-2):10-12.

135. Poole CB, Li Z, Alhassan A, et al. Colorimetric tests for diagnosis of filarial infection and vector surveillance using non-instrumented nucleic acid loop-mediated isothermal amplification (NINA-LAMP). PLoS One. 2017;12(2):e0169011.

136. Van den Enden E, Van Gompel A, Vervoort T, Van der Stuyft P, Van den Ende J. Mansonella perstans filariasis: failure of albendazole treatment. Ann Soc Belg Med Trop. 1992;72(3):215-218.

137. Bregani ER, Rovellini A, Mbaidoum N, Magnini MG. Comparison of different anthelminthic drug regimens against Mansonella perstans filariasis. Trans R Soc Trop Med Hyg. 2006;100(5):458-463.

138. Asio SM, Simonsen PE, Onapa AW. Mansonella perstans: safety and efficacy of ivermectin alone, albendazole alone and the two drugs in combination. Ann Trop Med Parasitol. 2009;103(1):31-37.

139. Perez-Molina JA, Diaz-Menendez M, Perez-Ayala A, et al. [Treatment of diseases caused by parasites]. Enferm Infecc Microbiol Clin. 2010;28(1):44-59. Spanish.

140. Diaz-Menendez M, Norman F, Monge-Maillo B, Perez-Molina JA, Lopez-Velez R. [Filariasis in clinical practice]. Enferm Infecc Microbiol Clin. 2011;29 Suppl 5:27-37. Spanish.

141. Gonzalez AA, Chadee DD, Rawlins SC. Ivermectin treatment of mansonellosis in Trinidad. West Indian Med J. 1999;48(4): 231-234.

142. Basano SA, Fontes G, Medeiros JF, et al. Sustained clearance of Mansonella ozzardi infection after treatment with ivermectin in the Brazilian Amazon. Am J Trop Med Hyg. 2014;90(6):1170-1175.

143. Krolewiecki AJ, Cajal SP, Villalpando C, Gil JF. Ivermectin-related adverse clinical events in patients treated for Mansonella ozzardi infections. Rev Argent Microbiol. 2011;43(1):48-50.

144. Casiraghi M, Favia G, Cancrini G, Bartoloni A, Bandi C. Molecular identification of Wolbachia from the filarial nematode Mansonella ozzardi. Parasitol Res. 2001;87(5):417-420.

145. Aljayyoussi G, Tyrer HE, Ford L, et al. Short-course, high-dose rifampicin achieves Wolbachia depletion predictive of curative outcomes in preclinical models of lymphatic filariasis and onchocerciasis. Sci Rep. 2017;7(1):210.

146. Clare RH, Cook DA, Johnston KL, Ford L, Ward SA, Taylor MJ. Development and validation of a high-throughput anti-Wolbachia whole-cell screen: a route to macrofilaricidal drugs against onchocerciasis and lymphatic filariasis. J Biomol Screen. 2015;20(1):64-69.

147. Taylor MJ, Hoerauf A, Townson S, Slatko BE, Ward SA. AntiWolbachia drug discovery and development: safe macrofilaricides for onchocerciasis and lymphatic filariasis. Parasitology. 2014;141(1): 119-127.

148. Klarmann-Schulz U, Specht S, Debrah AY, et al. Comparison of doxycycline, minocycline, doxycycline plus albendazole and albendazole alone in their efficacy against onchocerciasis in a randomized, openlabel, pilot trial. PLoS Negl Trop Dis. 2017;11(1):e0005156.

149. Fischer P, Tukesiga E, Büttner DW. Long-term suppression of Mansonella streptocerca microfilariae after treatment with ivermectin. J Infect Dis. 1999;180(4):1403-1405.

150. Regmi S, Callender T, Knox AF, Bhopal A. Research and development funding for 13 neglected tropical diseases: an observational economic analysis. Lancet. 2014;384(Spec Issue):S20.

151. Wanji S, Amvongo-Adjia N, Koudou B, et al. Cross-reactivity of filariais ICT Cards in areas of contrasting endemicity of Loa loa and Mansonella perstans in Cameroon: implications for shrinking of the lymphatic filariasis map in the central African region. PLoS Negl Trop Dis. 2015;9(11):e0004184. 
152. Bakajika DK, Nigo MM, Lotsima JP, et al. Filarial antigenemia and Loa loa night blood microfilaremia in an area without bancroftian filariasis in the Democratic Republic of Congo. Am J Trop Med Hyg. 2014;91(6):1142-1148.

153. Metenou S, Dembele B, Konate S, et al. Patent filarial infection modulates malaria-specific type 1 cytokine responses in an IL-10-dependent manner in a filaria/malaria-coinfected population. J Immunol. 2009;183(2):916-924.
154. Borkow G, Bentwich Z. Chronic parasite infections cause immune changes that could affect successful vaccination. Trends Parasitol. 2008;24(6):243-245.

155. Borkow G, Teicher C, Bentwich Z. Helminth-HIV coinfection: should we deworm? PLoS Negl Trop Dis. 2007;19:1(3):e160.

156. Borkow G, Bentwich Z. Eradication of helminthic infections may be essential for successful vaccination against HIV and tuberculosis. Bull World Health Organ. 2000;78(11):1368-1369.

\section{Publish your work in this journal}

Research and Reports in Tropical Medicine is an international, peerreviewed, open access journal publishing original research, case reports, editorials, reviews and commentaries on all areas of tropical medicine, including: Diseases and medicine in tropical regions; Entomology; Epidemiology; Health economics issues; Infectious disease; Laboratory science and new technology in tropical medicine; Parasitology; Public health medicine/health care policy in tropical regions; and Microbiology. The manuscript management system is completely online and includes a very quick and fair peer-review system. Visit http://www.dovepress. com/testimonials.php to read real quotes from published authors.

Submit your manuscript here: https://www.dovepress.com/research-and-reports-in-tropical-medicine-journal 